\title{
SILVER-CHEEKED TOADFISH, LAGOCEPHALUS SCELERATUS (ACTINOPTERYGII: TETRAODONTIFORMES: TETRAODONTIDAE), CAUSES A SUBSTANTIAL ECONOMIC LOSSES IN THE TURKISH MEDITERRANEAN COAST: A CALL FOR DECISION MAKERS
}

\author{
Vahdet ÜNAL ${ }^{1 *}$, Huriye GÖNCÜOĞLU ${ }^{1}$, Denizcan DURGUN ${ }^{2}, Z_{\text {afer TOSUNOĞLU }}^{1}$, \\ Mehmet Cengiz DEVAL ${ }^{3}$, and Cemal TURAN ${ }^{4}$ \\ ${ }^{1}$ Faculty of Fisheries, Ege University, Bornova, İmir, Turkey \\ ${ }^{2}$ Faculty of Agriculture, Ege University, Bornova, Izmir, Turkey \\ ${ }^{3}$ Faculty of Fisheries, Akdeniz University, Antalya, Turkey \\ ${ }^{4}$ Faculty of Marine Science and Technology, Iskenderun Technical University, İskenderun, Turkey
}

Ünal V., Göncüoğlu H., Durgun D., Tosunoğlu Z., Deval M.C., Turan C. 2015. Silver-cheeked toadfish, Lagocephalus sceleratus (Actinopterygii: Tetraodontiformes: Tetraodontidae), causes a substantial economic losses in the Turkish Mediterranean coast: A call for decision makers. Acta Ichthyol. Piscat. 45 (3): $231-237$.

Background. While some Lessepsian species provide economic benefits for Mediterranean fisheries, others cause economic losses. Lagocephalus sceleratus known as silver-cheeked toadfish poses a great risk to human health if consumed economic losses for fishers by damaging their fishing gears. This study aims to determine the socio-economic impact of silver-cheeked toadfish, with regards to its impact on biodiversity and socio-economic factors for small-scale fisheries.

Materials and methods. Face-to-face interviews were completed with a total of 261 fishers from Izmir in the Middle Aegean region to Hatay in the Eastern Mediterranean region, to determine the problems arising from the presence of silver-cheeked toadfish species in the ecosystem and the resulting associated economic losses for a 1-year from 1 January to 30 December 2011. The elements, which should be taken into account in calculating silver-cheeked toadfish related economic losses, are related to fishing gear, labour and the associated losses in catches. However, losses associated with silver-cheeked toadfish predation were beyond the scope of this study. Results. Almost all fishers (91\%) agree that silver-cheeked toadfish is a major problem, $82 \%$ believe that silver -cheeked toadfish negatively affects biodiversity, and $89 \%$ believe it lowers efficiency of their catches. Calculated silver-cheeked toadfish related losses were: $1300 \mathrm{TRY}^{* *}(\approx 442 \mathrm{EUR})$ per year, per fisherman; $263296 \mathrm{TRY}(\approx 89$ 521 EUR) per year, in total, for the interviewed fishers (261), and 204 fishers suffered economic losses relating to this species; which caused total losses of 6033577 TRY $(\approx 2051416$ EUR) per year in total for the 4719 fishers, which were $78 \%$ of all fishers (6051) in the study area. Two-thirds of the study respondents think that the most effective way to battle this problem would be to try to eliminate this species from Turkish waters. Among them, $32 \%$ of the fishers believe the most suitable gear to eliminate L. sceleratus from the marine ecosystem is the purse seine and $61 \%$ consent to fish L. sceleratus for 4 TRY each as a target species.

Conclusion. To start a bounty system and a premium payment for each pufferfish caught will both help to reduce negative impact of the species on the ecosystem and provide an extra income for the fishers.

Keywords: Lessepsian species, pufferfish, economic impact, socio-economics, bounty, small-scale fisheries

\section{INTRODUCTION}

The Intergovernmental Panel on Climate Change (IPCC) issued a report that stated that the effects of climate change are already occurring on all continents and across the oceans (Anonymous 2014a). It is also known that the Mediterranean Sea is in crisis because of global warming. Occhipinti-Ambrogi (2007) reported that the global climate change affecting the earth's atmospheric and oceanic system interacts in many ways with global biogeographic changes arising from marine species trans-

" Correspondence: Assoc. Prof. Dr. Vahdet Ünal, Ege Üniversitesi, Su Ürünleri Fakültesi, Bornova, İzmir, Turkiye, phone: +90 2323115226 , fax: +90 232311 374 7450, e-mail: (VÜ) vahdetunal@gmail.com, (HG) huriyegoncuoglu@gmail.com, (DU) denizcandurgun@gmail.com, (ZT) zafer.tosunoglu@ege.edu.tr, (MCD)deval@akdeniz.edu.tr, (CT) turancemal@yahoo.com.

*** Turkish lira $(\approx 0.34$ EUR) 
locations. Rising temperatures are aiding the establishment of foreign species into the Mediterranean. These species are mostly introduced via the Suez Canal and their successful establishment is believed to have been assisted in recent years by climate change. While some of these species_-such as Upeneus pori Ben-Tuvia et Golani, 1989; Upeneus moluccensis (Bleeker, 1855); and Nemipterus randalli Russell, 1986-generate economic benefit, others such as rabbit fish, Siganus luridus (Rüppell, 1829); and Siganus rivulatus Forsskål et Niebuhr, 1775) have been responsible for depleting algal concentrations in the Eastern Mediterranean (Sala et al. 2011), although they are of economic value. Recently, two Lessepsian pufferfish species attracted public attention: the silver-cheeked toadfish, Lagocephalus sceleratus (Gmelin, 1789) and the half-smooth golden pufferfish, Lagocephalus spadiceus (Richardson, 1845). The silver-cheeked toadfish, Lagocephalus sceleratus, raises significant problems both for the ecosystem and the fishers. It is the worst invasive species in the Mediterranean Sea due to its significant impact on the ecosystem and on the fisheries sector (Zenetos et al. 2005, Streftaris and Zenetos 2006, Öztürk 2010). The fish generates a poison called tetrodotoxin (TTX), which can be lethal to humans, and poses a great risk to human health when consumed (Nader et al. 2012). Arakawa (2010) reported that consumption of L. sceleratus is banned in Japan. Fishing and selling of pufferfish species are also banned in Turkey, Egypt, Cyprus, and Greece. In the Mediterranean, several cases of poisoning have been recorded as L. sceleratus is marketed regardless of the risk it poses to public health. Its large size might be one of the reasons behind this species being sold. There have already been 13 recorded cases of death in the Eastern Mediterranean as well as other cases of intoxication (Chamandi et al. 2009, Kalogirou et al. 2010).

The problem of Lagocephalus sceleratus was extensively discussed at the Technical Meeting on the Lessepsian Migration and Its Impact on Eastern Mediterranean Fishery in Nicosia, Cyprus, 7-9 December 2010, since this species is causing considerable damage to static nets and longlines, loss in catches of other species, thereby considerably reducing fishers income in all the countries in the Eastern Mediterranean (Anonymous 2010a). Kalogirou (2013) reported that 52 long-line hooks were found in 33 stomachs of the silver-cheeked toadfish. Complaints of fishermen included destruction of gillnets due to entangling or predation on already captured fish, reduction of local commercial catches of Sepia officinalis and Octopus vulgaris, cut-off of long-line hooks are confirming the pest status of $L$. sceleratus for commercial fishermen.

Lagocephalus sceleratus was first recorded in Turkish waters in February 2003 in Gökova Bay in Turkey (Akyol et al. 2005) and has since spread along the entire Mediterranean coast of Turkey up the Aegean coast. Landings of two pufferfish species: L. sceleratus and L. spadiceus) were banned in Turkey (Anonymous 2008).

Many studies on invasive pufferfish species were undertaken in the Mediterranean region (Galil 2007, Nader et al. 2012, Kalogirou 2013). Also several studies on pufferfish species, especially on Lagocephalus sceleratus, were carried out in Turkey and were subsequently reported in post-graduate theses (Irmak unpublished*, Y1ldirım unpublished $^{* *}$ ) and journal articles (Akyol et al. 2005, Bilecenoglu et al. 2006, Türker-Çakır et al. 2009, Torcu Koc et al. 2010, Aydin 2011). No studies, however, have been published on the socio-economic effects of these species, neither in Turkey nor in any other Mediterranean country, probably because the overall assessment of the impact of those fishes is indeed a very difficult task. Pimentel et al. (2005) estimated that costs associated with some alien fish species in the USA are 5.4 billion dollars. The estimates calculated in the presently reported study are considered conservative, as other associated economic losses are not yet known or not addressed. On the other hand, this study aims to determine the socio-economic problems caused by L. sceleratus and estimate the direct economic effects (simply loss) for the small-scale fishers in Turkey. Despite these shortcomings and constraints, this study is the first attempt to address socio-economic impacts of $L$. sceleratus not only in the Turkish coasts but also for the Mediterranean. Also documented for the first time, concrete quantitative socio-economic data are presented to decision makers to inform them of the situation affecting thousands of small-scale fishers faced with the problem of L. sceleratus.

\section{MATERIAL AND METHOD}

Study area. Turkey's total marine fish landings in 2011 was $477658 \mathrm{t}$ which constitutes $67.9 \%$ of the total fishery production. Fourteen \% of the marine fish landings is taken from the Turkish Mediterranean coasts (Anonymous 2012a). Although the Mediterranean is the least productive of the seas surrounding Turkey, it is rich in terms of its biodiversity and value of species. With similar value and biodiversity, the Aegean Sea (a subset of the Mediterranean Sea), despite its many bays and inlets, has limited fishing grounds due to its narrow continental shelf, and its deep and rocky seabed (Kinacigil and İlkyaz 1997). For similar reasons, the western and southern coasts of Turkey are dominated by the small-scale fisheries which are a vital sector for the coastal areas for reasons such as employment, production and catch value. In the coastal area where this study was conducted, there are 6051 small-scale fishing boats (Anonymous 2014b), 30 fishers' shelters or ports (Anonymous 2008), and 63 fishery cooperatives (Ünal et al. unpublished ${ }^{* * *}$ ).

Survey approach and questionnaire. The technique of direct communication with other people such as a ques-

\footnotetext{
" Irmak E. 2012. Türkiye kıyılarındaki Lessepsiyen balon balıklarının dağılımı ve beslenme özellikleri. [Lessepsian pufferfishes on the Turkish coasts and their feeding properties.] PhD Thesis. Çanakkale Onsekiz Mart University. [In Turkish.]

${ }^{* *}$ Yıldırım U.G. 2011. Akdeniz'de Lagocephalus sceleratus (Gmelin, 1789) türünün biyolojik özelliklerinin tespiti. [Determination of biological characteristics of Lagocephalus sceleratus (Gmelin, 1789) in Mediterranean.] MSc Thesis. Süleyman Demirel University. [In Turkish.]

*** Ünal V., Göncüoğlu H., Tosunoğlu Z., Yercan M. 2014. Deniz Balıkçıllı̆ı Yapan Su Ürünleri Kooperatiflerinin Profili. [Profile of marine capture fishery cooperatives.] Ege University Scientific Research Project No. 2010/SÜF/10. [In Turkish.]
} 
tionnaire interview is definitely more frequently applied. The study was conducted by interviewing fishers. A structured questionnaire consisting of 56 questions was prepared to collect data directly from the fishers and to outline the impacts of Lagocephalus sceleratus. Because an interview is a social interaction, the interviewer may influence the answers of the respondent. Consistency and correct methodological approach to questionnaire interviews has been emphasized by Głąbiński (2015). Therefore, we hired and worked with a professional interviewer from fisheries science to overcome with this problem which can bias the results of the study. Interviews were conducted efficiently by following only the instructions on the questionnaire. Each of the interviews was ended within the 35-50 min approximately.

The socio-economic impact of Lagocephalus sceleratus on coastal fishers along the Mediterranean coast of Turkey was analysed for a 1-year period from 1 January to 30 December 2011. The fishers who are owners of fishing boats were randomly selected in their geographical locations. Fishers who are owners of the fishing boats were interviewed individually to minimize the "group effect" bias. Face-to-face interviews were made with 261 fishers, from 26 fishing ports and villages in 7 cities along the $4382 \mathrm{~km}$ long Mediterranean coast of Turkey and the economic effects resulting from the inclusion of L. sceleratus in the ecosystem were quantified. Fig. 1 shows the map of Turkish Mediterranean costs with surveyed areas.

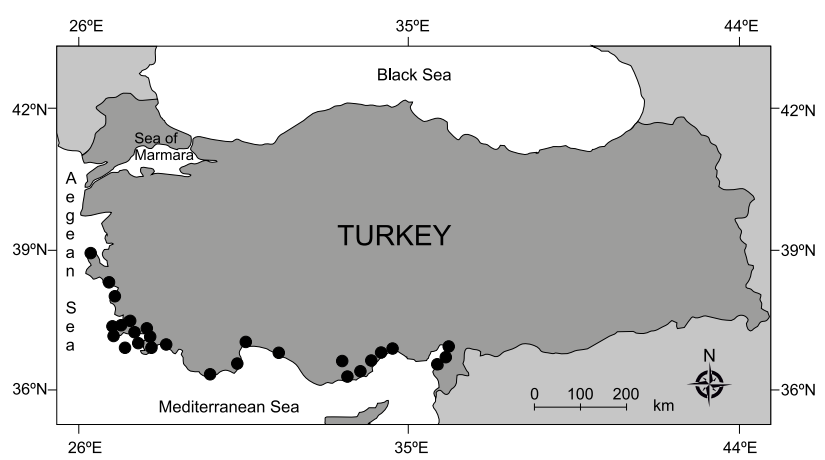

Fig. 1. The study area showing the sampled localities on the Mediterranean coast

The total number of small-scale fishing boats shorter than $12 \mathrm{~m}$ in İzmir, Aydın, Muğla Antalya, Mersin, Adana, and Hatay provinces is 6051 (Anonymous 2014b). The number of fishing boats required to be interviewed in order to accurately represent the population was determined by using the proportional sample size calculation formula.

Consider estimation of the proportion $C$ of individuals in a population size of $N$ who possess a certain attribute. If necessary, variance, $\sigma_{C}^{2}$, of the sample proportion is specified, the required sample size to estimate was calculated based on the formula (modified from Miran 2003 and Newbold 2013):

$$
n=\frac{N C(1-C)}{(N-1) \sigma_{C}^{2}+C(1-C)}
$$

where $n$ is the sample size, $N$ is the total population of target group, $C$ is the contribution ratio $(0.50$ is fitted to reach maximum sample size), and $\sigma_{C}^{2}$ is the variance.

The largest possible value of this expression, whatever the value of $C$, is

$$
n_{\max }=\frac{0.25 N}{(N-1) \sigma_{C}^{2}+0.25}
$$

A $90 \%$ confidence interval for the population proportion will extend approximately $1.645 \sigma_{c}=0.05 \quad\left(\sigma_{c}=0.0304\right)$ on each side of the sample proportion. So, the number of fishing boats to be sampled in the survey was found to be 259 , with $5 \%$ error margin and $90 \%$ confidence interval. The total number of fishers interviewed was 261 .

The survey was conducted in four parts. The first part gathered socio-demographic data such as age, marital status, level of education, social security, fishing experience, and other sources of income. The second part dealt with the characteristics of fishing operation variables (fishing days, fishing gear, mean daily costs, mean daily gross income, target species, etc.). In the third part, questions pertaining to the economic effects of Lagocephalus sceleratus (whether the species is considered as a problem, economic damage on fishing gears, other damages, awareness and expectations from authorities, most effective gear against L. sceleratus, and whether fishers would consider fishing the species if offered 1 or 4 TRY per fish) were asked. The final part of the survey consisted of photos of current pufferfish species-Lagocephalus sceleratus; Lagocephalus spadiceus; Lagocephalus suezensis Clark et Gohar, 1953; Torquigener flavimaculosus Hardy et Randall, 1983; and Tylerius spinosissimus (Regan, 1908) — spotted in the East Mediterranean (Golani et al. 2006). Fishers were questioned on how many different pufferfish species they catch, which pufferfish they catch and whether they are facing problem with the same pufferfish species or not.

Calculation of economic impacts. Measuring economic loss caused by invasive species such as pufferfish is a difficult task. In this study, data was collected from fishers based on their personal declarations and observation from time was spent with fishers at the field, on their boats while fishing, and of observed impacts of pufferfish on their fishing gears. In addition to above-mentioned efforts, face-to-face surveys were conducted to obtain the most reliable and detailed information.

In general, the economic losses related to Lagocephalus sceleratus consist of three elements: fishing gear losses, labour losses, and losses in the associated catches. However, losses in associated catches caused by L. sceleratus could not be determined from this study. Total economic losses to fishers related to L. sceleratus were calculated by multiplying the mean monetary value of the $L$. sceleratus-related damage to fishing gears by the total number of fishers interviewed, and adding those to related economic losses stemming from labour.

Lagocephalus sceleratus is known to damage the passive gears used especially by small-scale fishing boats 
along the Turkish coasts (Irmak unpublished*, Ünal et al. unpublished $^{* *}$, Yildırım unpublished ${ }^{* * *}$ ) Although the survey has questions targeting the economic loss of other fish species being caught in the gears because of L. sceleratus, it was difficult to attribute these losses to L. sceleratus with certainty as sharks, dolphins and/or Mediterranean monk seal could have also been the cause. Some fishers attempted to define the effects of pufferfish damages: "if the soft parts of the fish were eaten; if the tail, insides and fins were harmed, it was definitely done due to pufferfish". However, such observations could not be quantified numerically.

The study also revealed labour losses to fishers related to Lagocephalus sceleratus associated with longline operations. Based on the 2011 data of the Turkish Statistical Institute (Anonymous 2012b), the mean monthly wage of a permanent rural worker is 978.97 TRY ( $\approx 1.4$ EUR per hour). Consequently, a fisherman's mean labour loss was determined using the minimum wage and the time taken to repair the gear.

\section{RESULTS}

Characteristics of fishers and fishing systems in practice. The mean age of the fishers was $46 \pm 11$ years, with the youngest being 21 years of age and the oldest 83 years old. Fishers generally have primary education $(7 \pm 4$ years); however both illiteracy ( $9 \%$ ) and university graduation $(6 \%)$ were also observed. The mean value of the length of the fishing experience was found to be $24 \pm 11$ years. With a mean value of $3 \pm 2$ persons per household,

Table 1

Socio-demographic characteristics of fishers (2011-2012)

\begin{tabular}{|c|c|c|}
\hline Category & Variable & Value $[\%]$ \\
\hline \multirow[t]{5}{*}{ Age [years] } & $20-29$ & 6 \\
\hline & $30-39$ & 18 \\
\hline & $40-49$ & 35 \\
\hline & $50-59$ & 31 \\
\hline & $>60$ & 10 \\
\hline \multirow[t]{2}{*}{ Marital status } & Single & 17 \\
\hline & Married & 83 \\
\hline \multirow[t]{6}{*}{ Level of education } & Illiterate & 9 \\
\hline & Literate & 1 \\
\hline & 5 years of education & 45 \\
\hline & 8 years of education & 26 \\
\hline & 11 years of education & 13 \\
\hline & $>11$ years of education & 6 \\
\hline \multirow[t]{2}{*}{ Social security } & With social security & 67 \\
\hline & Without social security & 34 \\
\hline \multirow[t]{2}{*}{ Second income } & Fishing only & 55 \\
\hline & Having a second income & 45 \\
\hline Fishing experience & $1-10$ & 18 \\
\hline \multirow[t]{4}{*}{ [years] } & $11-20$ & 26 \\
\hline & $21-30$ & 31 \\
\hline & $31-40$ & 19 \\
\hline & $>41$ & 6 \\
\hline
\end{tabular}

fishers provide for $3 \pm 3$ family members excluding themselves. $83 \%$ of the fishers were married and one third of them had no social security of any kind. More than half of the fishers interviewed (55\%) report that they have no other income other than fisheries (Table 1).

Regarding their fishing gear preferences; $31 \%$ of the fishers in the study area used only longlines and $29 \%$ used only gillnets, $38 \%$ used both longlines and gillnets, and the remaining $2 \%$ used gears such as hand line, gillnet, and longline alternatively. Mean length of the trammel and gillnets were found to be $3819 \pm 6160 \mathrm{~m}$ and $2501 \pm$ $5684 \mathrm{~m}$, respectively. Mean number of hooks attached to a set by fishers using thin longlines was $865 \pm 781$ (Size 14); whereas the mean number of hooks on a thick longline was $877 \pm 1048$ with hook sizes 12 and up. The highest frequency $(41 \%)$ of income among the respondents was found to 501-1000 TRY ( $\approx 170-340$ EUR) per month; followed by1001-1500 TRY ( $\approx 340.3-510$ EUR) per month at $22 \%$. Mean number of fishing days and standard deviation in a year was found to be $200 \pm 73$. Fishing related findings are shown in Table 2.

Table 2

Characteristics of fishing operation variables per fishing boat or per fisherman within 2011-2012

\begin{tabular}{|c|c|c|}
\hline Category & Range or item & Value \\
\hline Fishing days & $30-89$ & 6 \\
\hline \multirow[t]{4}{*}{ per year [\%] } & $90-149$ & 15 \\
\hline & $150-209$ & 37 \\
\hline & $210-269$ & 23 \\
\hline & $>270$ & 20 \\
\hline \multirow[t]{4}{*}{ Fishing gear $[\%]$} & Longline & 31 \\
\hline & Longline and gillnets & 38 \\
\hline & Gillnets & 29 \\
\hline & $\begin{array}{l}\text { Longline, gillnets, and } \\
\text { angling }\end{array}$ & 2 \\
\hline \multirow{4}{*}{$\begin{array}{l}\text { Mean daily cost } \\
\text { [TRY per day] }\end{array}$} & Longline & 106 \\
\hline & Longline and gillnets & 75 \\
\hline & Gillnets & 81 \\
\hline & $\begin{array}{l}\text { Longline, gillnets and } \\
\text { angling }\end{array}$ & 25 \\
\hline \multirow{4}{*}{$\begin{array}{l}\text { Mean daily gross income } \\
\text { [TRY per day] }\end{array}$} & Longline & 197 \\
\hline & Longline and gillnets & 132 \\
\hline & Gillnets & 169 \\
\hline & $\begin{array}{l}\text { Longline, gillnets and } \\
\text { angling }\end{array}$ & 83 \\
\hline \multirow{7}{*}{$\begin{array}{l}\text { Income range } \\
\text { per fishermen } \\
\text { per day [\%] }\end{array}$} & $<500$ & 19 \\
\hline & $501-1000$ & 41 \\
\hline & $1001-1500$ & 22 \\
\hline & $1501-2000$ & 12 \\
\hline & $2001-2500$ & 3 \\
\hline & $2501-3000$ & 2 \\
\hline & $>3501$ & 0.8 \\
\hline
\end{tabular}

TRY $=$ Turkish lira $(\approx 0.34$ EUR $)$.

* See footnote on page 232

** Ünal V., Göncüoğlu H., Durgun D., Tosunoğlu Z., Deval C. 2013. Assessing economic impacts of pufferfish along the Turkish coast (Eastern Mediterranean. SAC meetings of the Sub-Committees, (SCSI, SCSA, SCESS, SCMEE), 13th Session of the Sub-Committee on Economic and Social Sciences (SCESS), 18-20 February 2013, FAO, HQ, Rome, Italy.

$* * *$ See footnote on page 232 
Socio-economic impacts of Lagocephalus sceleratus interference in fishing operations. First seen in the Mediterranean in 2003 (Akyol et al. 2005), L. sceleratus has been a problem for Turkish fishers since 2007. In the presently reported study, $91 \%$ of the fishers interviewed considered L. sceleratus a major problem for their fishing activity. Furthermore, $82 \%$ of them thought it had adverse effects on the diversity and the responses on adverse effects on the capture efficiency were also similarly high (89\%).

Longline fishers reported a loss of hooks; $76.7 \pm 426$ (mean $\pm \mathrm{SD}$ ), lost by Lagocephalus sceleratus biting them off to eat the bait caused a mean value of $16.7 \mathrm{~h}$ of extra labour per year to replace the hooks. Therefore a mean value of 67.9 TL per year, per fisher of labour cost has been included in the calculation of economic losses.

The study revealed that $78 \%$ of fisher's fishing gear was damaged by Lagocephalus sceleratus, with a mean value damage per vessel per year of $942( \pm 1008)$ TRY for those using longlines only, $1347( \pm 1451)$ TRY for gillnets/ trammel nets only, and $1441( \pm 901)$ TRY for those boats using both fishing gears (Table 3 ).

Table 3

Monetary losses related to gear damage caused by silver-cheeked toadfish, Lagocephalus sceleratus

\begin{tabular}{lccr}
\hline \multirow{2}{*}{ Gear type } & \multicolumn{3}{c}{ Monetary loss [TRY per day] } \\
\cline { 2 - 4 } & Mean $\pm \mathrm{SD}$ & Max & Min \\
\hline Longline & $942.4 \pm 1007.7$ & 5000.0 & 0.0 \\
Gillnets & $1346.9 \pm 1451.0$ & 5000.0 & 20.0 \\
Longline and gillnets & $1440.6 \pm 900.7$ & 5000.0 & 60.0 \\
\hline
\end{tabular}

$\mathrm{TRY}=$ Turkish lira $(\approx 0.34$ EUR $), \mathrm{SD}=$ standard deviation.

The total mean value loss of fisher reporting Lagocephalus sceleratus damages was calculated as 263-296 TRY ( $\approx 90-100$ EUR) per year (Table 4). Considering all the fishers in the area $(n=6051)$, a simple aggregation (value transfer) technique was used to determine the overall economic loss estimates for the entire smallscale fishing fleet along the Mediterranean coast of Turkey. Since $78 \%$ of the 261 fisher interviewed reported damages, for $78 \%$ of the small scale fishing boat owners in the area (6051 fishing boats), that equated to 4719 fishers, hence, the total mean value of the damage related to L. sceleratus was calculated at 6033577 TRY $(\approx 2051$ 416 EUR) per year.

Although $70 \%$ of the fishers reported that they are members of local fishery cooperatives, none of them have received support from the cooperatives for Lagocephalus sceleratus-induced damages. In this study, $99 \%$ of the fishers interviewed said that they had no support from any institution or cooperative in order to recover damages from L. sceleratus. The support reported by the remaining $1 \%$ was support received from the middlemen they worked with, for the replacement of their hooks.

In this study, $29 \%$ of the fishers admitted they have consumed Lagocephalus sceleratus at least once and con-
Table 4

Total monetary losses attributed to silver-cheeked toadfish, Lagocephalus sceleratus

\begin{tabular}{lcccc}
\hline \multirow{2}{*}{ Loss items } & \multirow{2}{*}{$n$} & \multicolumn{3}{c}{ Monetary loss [TRY per day] } \\
\cline { 3 - 5 } & & Mean \pm SD & Max & Min \\
\hline Gear loss & 204 & $1232.3 \pm 1076.2$ & 5000.0 & 10.0 \\
Labour loss & 137 & $67.9 \pm 215.5$ & 2.05 & 651.1 \\
Catch loss & 204 & $\mathrm{NE}$ & $\mathrm{NE}$ & $\mathrm{NE}$ \\
\hline
\end{tabular}

$n=$ number of cases, TRY $=$ Turkish lira $(\approx 0.34$ EUR $)$, $\mathrm{SD}=$ standard deviation; $\mathrm{NE}=$ not estimated.

sequently $18.5 \%$ of them have reported health issues following consumption.

Willingness to catch and fishing gear preferences in a hypothetical scenario. Fishers were asked to consider a hypothetical scenario in which a bounty program (buyback pufferfish species) is instated for 1 TRY return per caught pufferfish. When asked, 39\% of the fishers said they would be willing to target this species for 1 TRY per fish. When the price was increased to 4 TRY per pufferfish, the ratio increased up to $61 \%$ willingness to cooperate.

As for their answer for the most effective gear to catch pufferfish, $32 \%$ of the fishers chose purse seine, followed by longline $(21 \%)$, and gillnet and entangling net $(20 \%)$. Other gears chosen were trawl (16\%), spear $(6 \%)$, and hand line $(5 \%)$.

\section{DISCUSSION}

Considering the socio-economic impacts of Lagocephalus sceleratus on small-scale fishers is critical to the better monitoring of small-scale fisheries which play an important role not only in Turkey but also throughout the Mediterranean fisheries sector. The results of the presently reported survey confirm that the occurrence of L. sceleratus has negatively affected fishing operations and incomes of small-scale fishers in Turkey, in recent years. In fact, importance of the economic loss caused by the L. sceleratus is better understood if we look at the fishing income of fishers. The highest frequency $(41 \%)$ of fishing income was found to be the 501-1000 TRY $(\approx 170$ 340 EUR) per month per fisher in this study. This income level is far below the poverty line in the country.

Although did not estimate economic losses due to reduction in fish catches associated with Lagocephalus sceleratus predation, we did calculate economic losses due to damage to fishing gears and the number of manhours (additional labour cost) spent by the fishers in repairing fishing gear, which amounts to as much as 6033 577 TRY $(\approx 2051416$ EUR) per year for the Turkish small-scale fishing fleet along the Mediterranean coast of Turkey. Such an important impact caused by pufferfish, especially L. sceleratus, cannot be ignored by decision makers. The problem is still ongoing. It should be noted that losses are not limited only to damage of fishing gears and effects relating to additional labour costs. Lagocephalus sceleratus are also responsible for losses of 
other species caught in fishing gears. The figures of these losses are not easy to determine and are not given in this paper. Michailidis (2010) reported that the social and economic effects of the presence of $L$. sceleratus for the fisheries, as well as its impact on the ecosystem are very difficult to assess. However, although the present study was not able to provide an overall quantitative set of results in terms of total economic losses caused by pufferfish, this study should:

- Make decision-makers aware of the damage suffered by the fishers and,

- Inform the drafting of national policies addressing both prevention needs and compensation requests for the losses thereof. The findings from Irmak (unpublished*) revealed that pufferfish have been found to eat other commercial species of the families Sparidae and Scombridae already entangled in passive fishing gears. Due to these additional economic losses faced by commercial fishers, it is advised that further studies be directed at visually observing the scale of this pufferfish predation of entangled fish.

Small-scale fishing and fishers have a relatively new serious problem that was not an issue several years ago. With this new issue, deeper insight is needed not only to reflect on the status of fishers but also to assess future threats in order to mitigate and manage them.

Three urgent suggestions for decision makers are:

- To start a bounty system for fisheries;

- To start education and awareness program;

- To support research projects on alternative uses for Lagocephalus sceleratus in association with pharmaceutical companies.

Since the toxin is so strong in Lagocephalus sceleratus, those fish are not allowed to be used as fugu (the Japanese word for pufferfish and the traditional dish prepared from it) in Japan. Therefore potential use of their toxin in pharmaceutical industry could be considered which was also suggested by Nader et al. (2012).

The bounty system could be established to pay for every individual pufferfish caught. Such aid is given to farmers who are exposed to natural disaster or plagues of insects, and should be considered here for the smallscale fishers too. The bounty system was found to be a good idea by fishers in this study too, but important findings to be considered here are that with the payment of 1 TRY, only $39 \%$ of fishers reported that they would fish this species. However when the price was increased to 4 TRY per pufferfish, the percentage increased as high as $61 \%$. Bounty system is preferred in some countries' fisheries such as Turkish Republic of Northern Cyprus (Anonymous 2012c, Ulman et al. 2014). With a one-euro bounty on each individual subsidized by the fisheries management authorities, fishers have landed more than $15 \mathrm{t}$ of pufferfish in Southern Cyprus (Anonymous 2010 b). Regarding the support of new projects on alternative uses of this species, studies can be conducted so that the species could have various uses, for example, to extract its toxin for commercial applications. In con- clusion, findings and suggestions of the study have potentially important implications for setting priorities for related research and policies.

\section{ACKNOWLEDGEMENTS}

The presently reported study is a part of the Scientific Research Project Report No: 2011-SÜF-015 commissioned by the Ege University. The results were also presented in the Thirteenth Session of the GFCM-Scientific Advisory Committee (SAC) Sub-Committee on Economics and Social Sciences (SCESS) in FAO HQ, Rome, Italy, 18-20 February 2013. The authors gratefully thank the members of the SCESS for their critiques and Aylin Ulman for her assistance in English editing.

\section{REFERENCES}

Akyol O., Unal V., Ceyhan T., Bilecenoglu M. 2005. First confirmed record of Lagocephalus sceleratus (Gmelin, 1789) in the Mediterranean Sea. Journal of Fish Biology 66 (4): 1183-1186. DOI: $10.1111 /$ j.0022-1112.2005.00667.x

Anonymous 2008. Balikçi Barinaklari Yönetmeliği. [Fishing ports regulations.] Resmi Gazete 22846. [In Turkish.]

Anonymous 2010a. Report of the sub-regional technical meeting on the Lessepsian migration and its impact on Eastern Mediterranean fishery. FAO, EastMed Project, Athens. GCP/INT/041/EC-GRE-ITA/TD-04.

Anonymous 2010b. Report on presence of Legocephalus species coastal water of Cyprus. [updated 10.December.2014] Ministry of Agriculture, Natural Resources and Environment, Department of Fisheries and Marine Research.

Anonymous 2012a. Su Ürünleri İstatistikleri. [Fishery statistics 2011. Turkish Statistical Institute.] Ankara, October 2012, No. 3876, 57 pp. ISSN 1013-6177 [In Turkish.]

Anonymous 2012b. Labour force statistics 2011. [updated 10.December.2014] http://tuikapp.tuik.gov.tr/isgucuapp/isgucu.zul?dil=2 [In English.]

Anonymous 2012c. Balon baliklarinin toplatilmasi. Karar no: 1621/2012, Önerge no: K(II) 1697-2012. [Withdrawl of the Puffer fish species from the fishermen. Motion. No: 1621/2012, Resolution number: K(II) 1697-2012.] Ministry of Agriculture and Natural Resources, Turkish Republic of Northern Cyprus. [In Turkish.]

Anonymous 2014a. A changing climate creates pervasive risks but opportunities exist for effective responses. The Intergovernmental Panel on Climate Change Report: Press Release https://www.ipcc.ch/pdf/ar5/ pr_wg2/140330_pr_wgII_spm_en.pdf

Anonymous 2014b. Balikcilik Bilgi Sistemi. [Fisheries Information System.] [Updated 10 December 2014.] http://subis.tarim.gov.tr/ [In Turkish.]

Arakawa O., Hwang D.-F., Taniyama S., Takatani T. 2010. Toxins of pufferfish that cause human intoxications. Pp. 227-244. In: Ishimatsu A., Lie H.-J. (eds.) 
Coastal environmental and ecosystem issues of the East China Sea. TERRAPUB and Nagasaki University, Japan.

Aydın M. 2011. Growth, reproduction and diet of pufferfish (Lagocephalus sceleratus Gmelin, 1789) from Turkey's Mediterranean Sea coast. Turkish Journal of Fisheries and Aquatic Sciences 11 (4): 569-576. DOI: 10.4194/1303-2712-v11_4_10

Bilecenoglu M., Kaya M., Akalin S. 2006. Range expansion of silverstripe blaasop, Lagocephalus sceleratus (Gmelin, 1789), to the northern Aegean Sea. Aquatic Invasions 1 (4): 289-291.

DOI: 10.3391/ai.2006.1.4.14

Chamandi S.C., Kallab K., Mattar H., Nader E. 2009. Human poisoning after ingestion of puffer fish caught from Mediterranean Sea. Middle East Journal of Anaesthesiology 20 (2): 285-288.

Galil B.S. 2007. Loss or gain? Invasive aliens and biodiversity in the Mediterranean Sea. Marine Pollution Bulletin 55 (7-9): 314-322.

DOI: 10.1016/j.marpolbul.2006.11.008

Głąbiński Z. 2015. The application of social survey methods in analysing the tourist activity of seniors. 27 (27): 51-65.

DOI: 10.1515/bog-2015-0004

Golani D., Öztürk B., Başusta N. 2006. Fishes of the eastern Mediterranean. Turkish Marine Research Foundation. Publication No. 24. Istanbul, Turkey.

Kalogirou S. 2013. Ecological characteristics of the invasive pufferfish Lagocephalus sceleratus (Gmelin, 1789) in Rhodes, Eastern Mediterranean Sea. A case study. Mediterranean Marine Science 14 (2): 251-260. DOI: $10.12681 / \mathrm{mms} .364$

Kalogirou S., Corsini-Foka M., Sioulas A., Wennhage H., Pihl L. 2010. Diversity, structure and function of fish assemblages associated with Posidonia oceanica beds in an area of the eastern Mediterranean Sea and the role of non-indigenous species. Journal of Fish Biology 77 (10): 2338-2351.

DOI: $10.1111 / \mathrm{j} .1095-8649.2010 .02817 . \mathrm{x}$

Kınacıgil H.T., İlkyaz A.T. 1997. Ege Denizi Balıķçı̆̆ı̆. [Sea fisheries in the Aegean Sea.] Ege University Journal of Fisheries and Aquatic Sciences 14 (3-4): 351367. [In Turkish.]

Michailidis N. 2010. Study on the Lessepsian migrant Lagocephalus sceleratus, in Cyprus. Report of the Technical meeting on the Lessepsian migration and its impact on Eastern Mediterranean fishery. GCP/ INT/041/EC-GRE- ITA/TD-04. FAO-EastMed Project, Athens.

Miran B. 2003. Temel İstatistik. [Basic Statistics.] Ege University Publishing House, İzmir, Turkey. [In Turkish.]

Nader M., Indray S., Boustany L. 2012. The pufferfish Lagocephalus sceleratus (Gmelin, 1789) in the Eastern Mediterranean. FAO-EastMed Project, Athens, Greece. GCP/INT/041/EC-GRE-ITA/TD-10.

Newbold P., Carlson W.L., Thorne B.M. 2013. Statistics for business and economics. Global edition. Pearson Education Limited.
Occhipinti-Ambrogi A. 2007. Global change and marine communities: Alien species and climate change. Marine Pollution Bulletin 55 (7-9): 342-352.

DOI: $10.1016 /$ j.marpolbul.2006.11.014

Öztürk B. 2010. Status of alien species in the Black and Mediterranean Seas. P. 103. In: Studies and Reviews. General Fisheries Commission for the Mediterranean. No. 87. FAO, Rome.

Pimentel D., Zuniga R., Morrison D. 2005. Update on the environmental and economic costs associated with alien-invasive species in the United States. Ecological Economics 52 (3): 273-288. DOI: $10.1016 /$ j.ecolecon.2004.10.002

Sala E., Kizilkaya Z., Yildirim D., Ballesteros E. 2011. Alien marine fishes deplete algal biomass in the Eastern Mediterranean. PLoS ONE 6 (2): e17356. DOI: 10.1371 journal.pone.0017356

Streftaris N., Zenetos A. 2006. Alien marine species in the Mediterranean - the 100 'worst invasives' and their impact. Mediterranean Marine Science 7 (1): 87-118. DOI: $10.12681 / \mathrm{mms} .180$

Torcu Koc H., Erdogan Z., Ustun F. 2011. Occurence of the Lessepsian migrant, Lagocephalus sceleratus (Gmelin 1789) (Osteichtyes: Tetraodontidae), in Iskenderun Bay (north-eastern Mediterranean, Turkey). Journal of Applied Ichthyology 27 (1): 148-149. DOI: $10.1111 /$ j.1439-0426.2010.01628.x

Türker-Çakır D., Yarmaz A., Balaban C. 2009. A new record of Lagocephalus sceleratus (Gmelin 1789) confirming a further range extension into the northern Aegean Sea. Journal of Applied Ichthyology 25 (5): 606-607.

DOI: $10.1111 /$ j.1439-0426.2009.01276.x

Ulman A., Çiçek B. A., Salihoglu I., Petrou A., Patsalidou M., Pauly D., Zeller D. 2014. Unifying the catch data of a divided island: Cyprus's marine fisheries catches, 1950-2010. Environment, Development and Sustainability 16 (4): 801-821.

DOI: $10.1007 / \mathrm{s} 10668-014-9576-\mathrm{z}$

Zenetos A., Çinar M.E., Pancucci-Papadopoulou M.A., Harmelin J.G., Furnari G., Andaloro F., Bellou N., Streftaris N., Zibrowius H. 2005. Annotated list of marine alien species in the Mediterranean with records of the worst invasive species. Mediterranean Marine Science 6 (2): 63-118.

DOI: $10.12681 / \mathrm{mms} .186$

Received: 23 December 2014 Accepted: 20 April 2015

Published electronically: 30 September 2015 